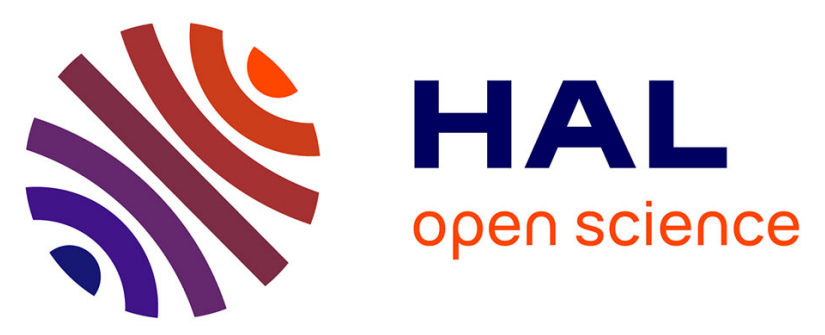

\title{
Electricity generation analyses in an oil-exporting country: Transition to non-fossil fuel based power units in Saudi Arabia
}

Arash Farnoosh, Frédéric Lantz, Jacques Percebois

\section{- To cite this version:}

Arash Farnoosh, Frédéric Lantz, Jacques Percebois. Electricity generation analyses in an oil-exporting country: Transition to non-fossil fuel based power units in Saudi Arabia: Cahiers de l'Economie, Série Recherche, $n^{\circ}$ 92. 2013. hal-02474811

\section{HAL Id: hal-02474811 https: / hal-ifp.archives-ouvertes.fr/hal-02474811}

Preprint submitted on 11 Feb 2020

HAL is a multi-disciplinary open access archive for the deposit and dissemination of scientific research documents, whether they are published or not. The documents may come from teaching and research institutions in France or abroad, or from public or private research centers.
L'archive ouverte pluridisciplinaire HAL, est destinée au dépôt et à la diffusion de documents scientifiques de niveau recherche, publiés ou non, émanant des établissements d'enseignement et de recherche français ou étrangers, des laboratoires publics ou privés. 

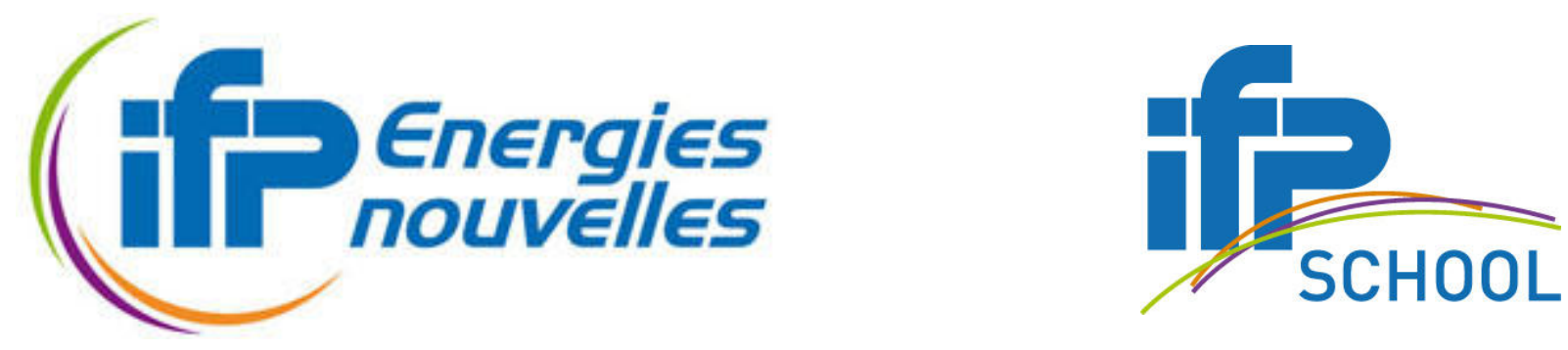

\title{
Electricity generation analyses in an oil-exporting country: Transition to non-fossil fuel based power units in Saudi Arabia
}

\author{
Arash FARNOOSH \\ Frédéric LANTZ \\ Jacques PERCEBOIS
}

Décembre 2013

\section{Les cahiers de l'économie - $\mathbf{n}^{\circ} 92$}

\section{Série Recherche}

\author{
arash.farnoosh@ifpen.fr
}

\begin{abstract}
La collection "Les cahiers de l'économie" a pour objectif de présenter des travaux réalisés à IFP Energies nouvelles et à IFP School, travaux de recherche ou notes de synthèse en économie, finance et gestion. La forme peut être encore provisoire, afin de susciter des échanges de points de vue sur les sujets abordés. Les opinions émises dans les textes publiés dans cette collection doivent être considérées comme propres à leurs auteurs et ne reflètent pas nécessairement le point de vue d' IFP Energies nouvelles ou d' IFP School.
\end{abstract}

The views expressed in this paper are those of the authors and do not imply endorsement by the IFP Energies Nouvelles or the IFP School. Neither these institutions nor the authors accept any liability for loss or damage incurred as a result of the use of or reliance on the content of this publication. 



\title{
Electricity generation analyses in an oil-exporting country: Transition to non-fossil fuel based power units in Saudi Arabia ${ }^{*}$
}

Arash FARNOOSH $^{\mathrm{a} * *}$, Frederic LANTZ ${ }^{\mathrm{a}} \& \mathrm{~J}^{\mathrm{acques}}$ PERCEBOIS $^{\mathrm{b}}$

${ }^{a}$ IFP Énergies Nouvelles, IFP School, 228-232 Avenue Napoléon Bonaparte, F-92852 Rueil-Malmaison, France

${ }^{\mathrm{b}}$ Université Montpellier 1 - UFR d'Economie - CREDEN (Art-Dev UMR CNRS 5281), Avenue Raymond Dugrand. CS 79606 - 34960 Montpellier, France

\begin{abstract}
In Saudi Arabia, fossil-fuel is the main source of power generation. Due to the huge economic and demographic growth, the electricity consumption in Saudi Arabia has increased and should continue to increase at a very fast rate. At the moment, more than half a million barrels of oil per day is used directly for power generation. Herein, we assess the power generation situation of the country and its future conditions through a modelling approach. For this purpose, we present the current situation by detailing the existing generation mix of electricity. Then we develop a optimization model of the power sector which aims to define the best production and investment pattern to reach the expected demand. Subsequently, we will carry out a sensitivity analysis so as to evaluate the robustness of the model's by taking into account the integration variability of the other alternative (non-fossil fuel based) resources. The results point out that the choices of investment in the power sector strongly affect the potential oil's exports of Saudi Arabia.
\end{abstract}

Keywords: Electricity Generation Model; Saudi Arabia; Power Generation Mix

* A preliminary version of this article was presented at the North American Energy Economics Association in Austin-Texas in November 2012.

** Corresponding author. Tel.: +33 147526374 \& E-mail address: arash.farnoosh@ifpen.fr 


\section{Introduction}

Saudi Arabia with around one-fifth of the world's proven oil reserves is the biggest oil producer in the Organization of Petroleum Exporting Countries (OPEC). With important investments in the oil sector and low production costs, Saudi Arabia is likely to remain the world's largest net oil exporter. Thus, the Saudia oil production is 544 million of tons (Mt) in 2011 and the net exports reach $355 \mathrm{Mt}$ for the same year (IEA, 2012)

Over the next two decades, Saudi's power generation capacity is predicted to reach 120 gigawatt-electric (GWe) (SEC 2010). The combination of Saudi Arabia's rapidly expanding population and industrial infrastructure, along with low electricity tariffs, has increased the demand on electricity utilities (averaging $8 \%$ annual growth over the period). This dramatic load increase has led to shortages, brownouts, blackouts and power rations in various parts of the country. Electricity demand which now stands at around 50GWe, around 200 terawatt hours (TWh) of yearly production, is predicted by the government to increase from $80 \mathrm{GWe}$ by 2020 to more than $120 \mathrm{GWe}$ by $2030 .{ }^{1}$ Figure 1 , illustrates this increase of power production.

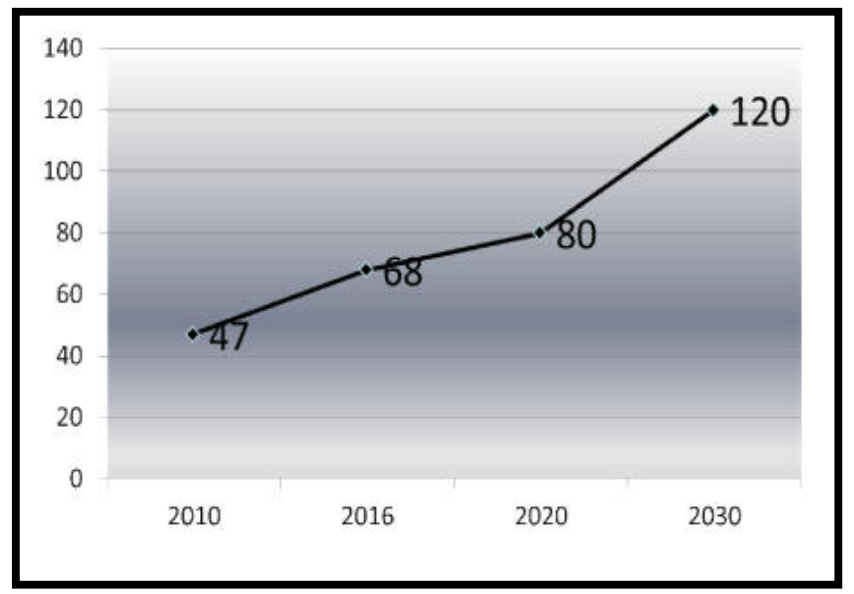

Figure 1: Power generation growth forecast in GW for Saudi Arabia

(Source: SEC/KACARE 2010)

\footnotetext{
${ }^{1}$ Electricity and cogeneration regulatory authority 2010.
} 
For the time being in Saudi Arabia, 100\% of power generation is based on the fossil fuel sources (oil \& gas). Figure 2 and figure 3 show respectively the share of different power units and fuels in the power generation mix of the country. Increasing oil and gas domestic consumption and the resulting impact on export revenues is not a very good option for the Saudi government due to both economic and political reasons. In this paper, we evaluate the present and future potential of using non-fossil fuel based energy in the power sector of this country.

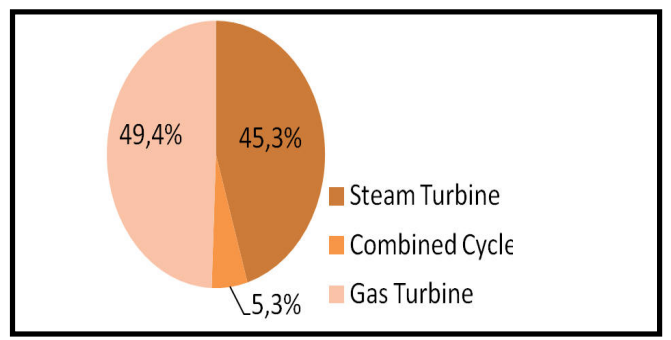

Figure 2: Existing generation capacity profile in Saudi Arabia

(Source: SEC 2010)

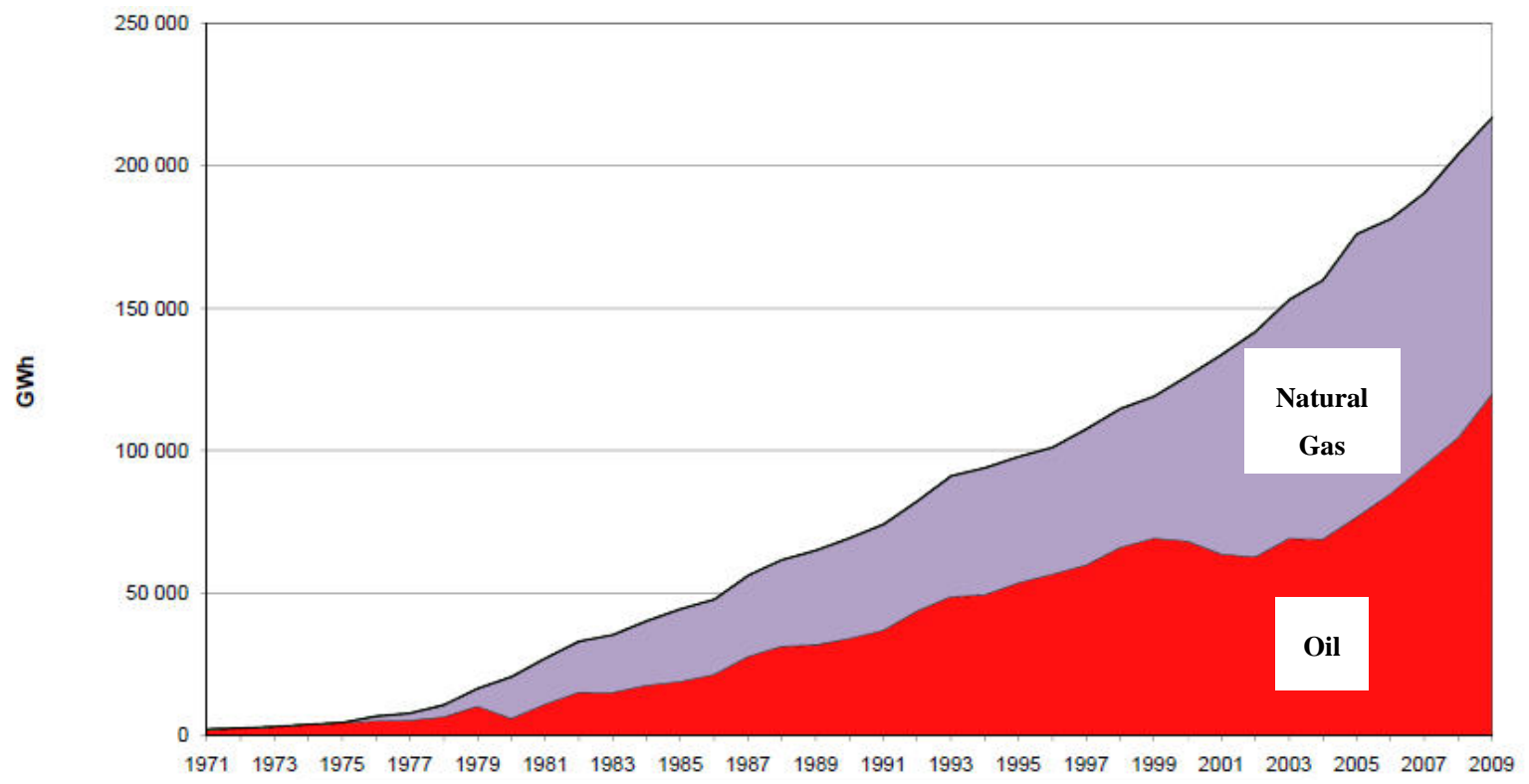

Figure 3: Electricity generation by fuel in Saudi Arabia (Source: OECD/IEA 2011)

A linear programming optimization framework was used to assess the costs and savings of expanding the role of non-fossil fuel based power sources in electricity supply. LP (Linear 
programming) cost minimizing is an approach that systematically evaluates potential power supply to satisfy the demand at the best societal cost. In this study, we analyse what the incremental cost would be if each sources of power generation were to integrate the electricity supply of the country. In pursuit of this objective, we provide a review of relevant non-fossil and fossil based power unit choices on the basis of resource potential, cost and economic benefits. Several choices of technologies that are or are expected to be technically and economically feasible over the next two decades have been identified and incorporated into the modelling effort.

\section{Methodology}

Electricity generation should be provided by a large set of power plants which are characterized by different technologies associated to a very large spectrum of fixed and running (variable) costs. Consequently, this leads to an optimal usage and investments so as to satisfy the current and future demand. Optimizing the overall electricity cost of production from different types of plants enables us to rank the existing production units. Indeed, when the electricity demand increases and the available power (in the lowest cost category) is not enough, producer must switch to the generation unit whose cost category is just one step above the previous one. In other words, we rank the use of power plants according to their growing variable cost (so-called "merit-order" process).

The main contribution of this study is to analyse an optimal pattern of the Saudi power generation mix through an LP model (based on the above-mentioned structure) and to reveal the impact of renewable and nuclear integration into the electric system under different penetration-range scenarios. Afterwards, the financial and economic gains (or perhaps losses) will be quantified by looking at the amount of fossil-fuel probably released and injected to the market instead of internal/national usage in the power sector. 
Total electricity generation cost minimization, is one of the main modelling approaches in power generation modelling. Examples of such models include POLES ${ }^{2}$ (Criqui 2001), MARKAL $^{3}$ and TIMES $^{4}$ (Loulou et al. 2004). The main idea of these models is to explain electricity prices from the marginal generation cost. In this case, assumption over the future electricity prices does not have to be made. Focusing on minimum generation cost implies minimizing the cost to be transferred to the final consumers, irrespective of the electricity price. The key advantage of this method is to analyse the producer behaviour facing with a mix of deferent types of constraints such as economic, technical and environmental ones. Our approach is similar, in the way that we develop a model where the total costs are to be minimized under certain constraints and scenarios developed in the next section.

\section{Power Generation Means in Saudi Arabia}

Before the power generation model construction, we analyse the potential of different nonfossil fuel based technologies such as geothermal, wind, solar and nuclear in Saudi Arabia. Feasibility studies have been realized in order to identify the most suitable and reliable technologies for this region based on the technical, economic and geographical characteristics. Due to the climate and regional properties of this country, some power units are not supposed to be useful and adapted to the national generation mix. In the following, we analyse each technology in detail and try to find out those who can be considered for the Saudi power generation mix from climatic, economic and technological point of view. Finally, the existing thermal power units in Saudi Arabia have been described.

\footnotetext{
${ }^{2}$ Prospective Outlook on Long term Energy Systems

${ }^{3}$ MARKet ALlocation

${ }^{4}$ The Integrated MARKAL-EFOM System
} 


\subsection{Geothermal Energy}

While not really abundant, geothermal energy potential does exist in Saudi Arabia (Alnatheer 2006). This technology is not entirely a renewable resource since the geothermal wells can be depleted over time. These resources belong to two types of technology, either hydrothermal or hot dry rock. Binary and flash technologies are the main approaches generally used to extract heat from geothermal wells. Although initial investment costs of the plant are relatively high, geothermal energy could become economically competitive (on a life cycle basis) to other sources of power generation (Boyle 2004).

Some studies have suggested the potential of combined solar and geothermal power so as to provide water and electricity in Saudi Arabia (Oktun \& Sayigh 1976). Saudi Arabia is somehow rich in terms of various geological features, with around 10 hot springs located in the regions of Gizan and Al Lith in the southern part of the country (Taleb 2009). Some of these thermal springs could be utilized for electricity generation, even though none have yet been exploited (Lund et al. 2005). Alnatheer (2006) argued that the exploitation of geothermal energy in Saudi Arabia is not cost-effective, even when compared with other renewable sources such as solar and wind power. Moreover, a set of renewable power sources scenarios were developed for Saudi Arabia in a study provided by Al-Saleh et al. (2008) in which the prospects of geothermal energy (both power and heat) were not considered as being sufficiently viable. Taleb (2009) identified both technical and non-technical barriers of geothermal energy utilization in Saudi Arabia. The most important reasons which are claimed are the uncertainty regarding available resources (the lack of technical feasibility studies), the lack of financial incentives and high capital cost of this technology (compared to the power generation based on oil), and the poor public acceptance of renewable energy sources in general and particularly geothermal one and lack of neither academic nor professional training in this field. 
At last, due to the above mentioned arguments and existing barriers for the development of this technology in Saudi Arabia, we don't consider the integration of geothermal energy as an option for the future energy mix of the country (neither in the optimization model nor in its associated scenarios).

\subsection{Wind Energy}

There are many locations in Saudi Arabia that the annual speed of wind (averaged) goes beyond $4 \mathrm{~m} / \mathrm{s}$ at a height of around 20m. Al-Abbadi (2004) showed that the wind annual average speed can reach even $5.7 \mathrm{~m} / \mathrm{s}$ and $5.4 \mathrm{~m} / \mathrm{s}$ in Dhulum and Arar sites respectively for speeds higher than $5 \mathrm{~m} / \mathrm{s}$ for around $50 \%$ of the time. In spite of this rather high potential wind power in Saudi Arabia (compare to the other Persian Gulf CCG countries) there is not an upright future for this energy in this country, at least in the short and medium terms. In fact, the highest and most optimistic wind energy potential in Saudi Arabia was estimated to yield around 20 TWh per year (Alnaser 2009). This is a considerable amount seeing the climatic conditions of the region but compare to the other renewable options such as solar (both concentrated and photovoltaic); it does not represent even $1 \%$ of their estimated potential.

Therefore in this study we won't consider wind energy as a high potential option for the future power generation mix of the country due to its negligible potential and huge costs (currently) compare to conventional plants. Moreover, there has not been any official declaration from the government or any energy authority regarding a vast investment in this area up to now. And the existing projects are all at a very small scale (decentralized) or are just under R \& D and pilot stages.

\subsection{Solar Energy}

Solar energy has been accepted as a key source of energy for the future in Saudi Arabia. Saudi Arabia has enormous potential for exploiting solar energy. Its geographical location, 
widespread unused desert land and clear skies, make it an excellent candidate for this technology. The average solar radiation falling on the Arabian Peninsula is around 2200KWh/m² per year (Hepbasli \& Alsuhaibani 2011).

According to the Saudi Solar Radiation Atlas which is a governmental document concerning the solar radiation of the country, Saudi Arabia has vast areas subject to strong $\mathrm{GHI}^{5}$ and fractions of $\mathrm{DNI}^{6}$ which are respectively ideal for Photovoltaic (PV) and Concentrating Solar Power (CSP) technologies.

Just for giving an example, within about $2000 \mathrm{KWh} / \mathrm{m}^{2} / \mathrm{y}$ of DNI, it has been estimated that the potential annual energy yield of CSP technology in Saudi Arabia is around 124,560 TWh. ${ }^{7}$ This amount represents around 650 times the total electricity consumption of the country in 2009. This reflects the fact that CSP technology must be considered between the most suitable renewable technologies in the Saudi's future energy mix. Hence, in this study and in our model's scenarios we do consider solar option in the future electricity generation mix of the country. Load factors considered for both PV and CSP technologies in the model are respectively equal to 0.2 and 0.34 (K.A. CARE 2010).

\subsection{Nuclear Power}

Nuclear power generation provides around $7 \%$ of the world primary energy supply and about $14.7 \%$ of the electric power generation. ${ }^{8}$ Increasing improvements in safety means, using experience, plant availability and of course economy, made nuclear energy competitive with other means of electricity generation. For the time being 436 nuclear reactors generate around $370 \mathrm{GW}$ of electric power all around the world (IEA 2011). While there are many reactors in operation in the US, Europe, Japan and China, the other regions of the world do not use this

\footnotetext{
${ }^{5}$ Global Horizontal Irradiance which is equal to the total solar radiation.

${ }^{6}$ Direct Normal Irradiance which is equal to direct beam radiation.

${ }^{7}$ German Aerospace Center (DLR) report, 2010. Concentrating Solar Power.

${ }^{8}$ Nuclear Energy Outlook 2008.
} 
technology within a significant amount. In Africa, it is only South African Republic which has two operating reactors providing only $1.8 \mathrm{GWe}$ of electricity. In the Middle-East only one nuclear power plant with the capacity of $1 \mathrm{GWe}$ is operating in Iran. Despite of the large diversity in term of design, only two types of reactor dominate nuclear power generation. $85 \%$ of operating reactors are the light water type reactors including the Russian RBMK reactor. Majority of these reactors are Pressurized Water type reactors and the rest of it are boiling water ones. Both technologies use slightly enriched Uranium (3-5\%) as fuel which does not create any potential proliferation risk. Nuclear fuel, in contrary to oil and gas resources, has extended life time and is not considered as a depleting resource.

Therefore, this technology is not a negligible source of electric power choice for Saudi Arabia as an energy source (the model will tell us more about its economic viability) and we consider it in our model's scenarios. Moreover, Saudi government has recently announced its intention to use this technology for the future power generation. According to the government officials, Saudi Arabia plans to build about 16 nuclear power reactors, with the capacity of around 20GWe, over the next 20 years by spending around $\$ 7$ billion on each plant. This $\$ 112$ billion investment plan (total 16 reactors) is supposed to provide one-fifth of the Saudi Arabia electricity generation for residential and industrial usage and in some cases for desalination of sea water which is very critical for this country. Most likely, the reactor locations will be along the Persian Gulf or Red Sea.

\subsection{Thermal fossil-fuel-based power plants and their situation}

Currently, electricity production in Saudi Arabia comes thoroughly from thermal equipment family, except coal and nuclear ones. Hence, the current electricity supply system in our optimization model is composed of only this type of power plants. Their operating principle is as following: combustion can heat a fluid which produces, in a turbine, mechanical energy 
converted into electrical one by a generator. There are currently three main types of thermal fossil-fuel-based power plant in Saudi Arabia:

First, the gas turbines whose exhaust gases produced directly goes for the energy required to drive the alternator. Efficiency of this mode of production is relatively low (15 to 30\%) and operating costs, including fuel which accounts for most of them, are very important. However, gas turbine power plant has two major advantages over competing modes of production: first the investment cost is relatively low and secondly they have the distinction of being immediately available with a very low starting time. Gas turbine is an ideal element when used for a short period, when it is necessary to significantly and rapidly increase the production capacity to meet the demand. Hence, they are very adapted to be used during peak loads. Hail-2 power plant located in the Hail in Saudi Arabia is an example of this sort of thermal unit.

Second type is the combined cycle, which consists of installing counter-pressure (steam turbine) in addition to the gas turbine so as to maximize the electricity production. Indeed, it offers the opportunity to at least triple the production of electricity for the same heat, which can lead to overall efficiency of 50 to $60 \%$. Ras Tanura power plant located in the Ash Sharqiyah belongs to this family of thermal units.

Finally the conventional thermal stations with two versions: the thermal oil and thermal coal. The operating principle consists of burning oil or coal to heat a fluid (most often it is the water steam) and then expansion of this fluid through a turbine that drives a generator. Despite a low overall efficiency (electricity produced is only $30-35 \%$ of energy input); it remains higher than that of Gas Turbines. In addition, operating costs are relatively low and allow to partially offsetting the heavy investment costs. However, these plants are very slow to start and ramp up, so they are not suited to respond quickly to a sudden increase in demand. 
Shuaibah power plant with the capacity of $3 * 400$ MW (gross) is an example of thermal oil units.

Figure 4 shows the locations of these power plants for all the four operating areas in Saudi Arabia: Eastern, Central, Western and Southern.

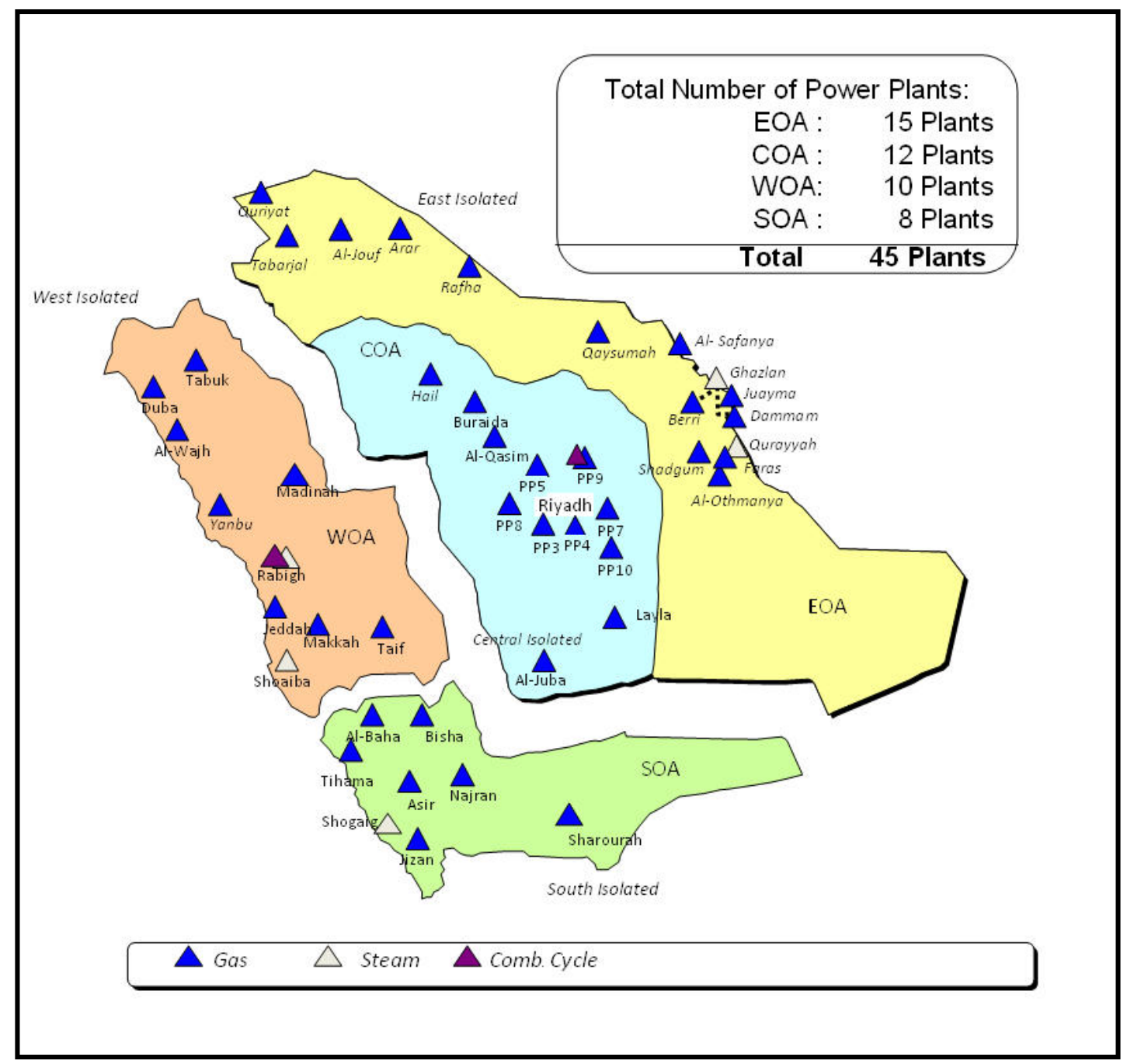

Figure 4: Existing power plants in Saudi Arabia (Source: Saudi Electricity Company 2009) 


\section{Modelling frame-work}

We model the current power generation mix structure of the country by using GAMS (General Algebraic Modelling System) software. This cost minimization model contains the objective cost function that must be minimized and the demand constrains that have to be satisfied. For static short-term optimization (base year 2010), the production capacities must be respected and in the case of long-term optimization, investments are allowed. The model structure is as following:

$$
\begin{aligned}
& \operatorname{Min}\left[\sum_{\mathrm{i}} \sum_{\mathrm{s}} \mathrm{H}_{\mathrm{s}} \times \mathrm{E}_{\mathrm{it}} \times \mathrm{p}_{\mathrm{ist}}+\sum_{\mathrm{i}} \mathrm{I}_{\mathrm{it}} \mathrm{C}_{\mathrm{it}}\right] \\
& \frac{1}{\tau_{\text {is }}} \mathrm{P}_{\mathrm{ist}} \leq \mathrm{C}_{\mathrm{it}} \\
& \sum_{\mathrm{i}} \mathrm{P}_{\mathrm{ist}} \geq \mathrm{D}_{\mathrm{st}}-\mathrm{AP}_{\mathrm{t}}
\end{aligned}
$$

In which,

$\mathrm{P}_{\mathrm{ist}}$ is the Power loaded on the grid by each equipment of type $i$, for the season $s$ in year $t$ (MW)

$\mathrm{C}_{\mathrm{it}}: \quad$ The capacity of the equipment of type $i$ in year $\mathrm{t}(\mathrm{MW})$

$\mathrm{H}_{\mathrm{S}}$ : Length of the season $s$ (hours)

$\mathrm{I}_{\mathrm{it}} \quad$ Investment cost of each unit of production $(\$ / \mathrm{kW})$

$\mathrm{E}_{\mathrm{it}} \quad \quad$ Variable cost of production for each equipment $i(\$ / \mathrm{kWh})$

$\mathrm{D}_{\mathrm{st}} \quad$ Called power on the grid for the season $s$ (MW) 
$\tau_{\text {is: }} \quad$ Coefficient of availability in each season for each equipment $i$

$\mathrm{AP}_{\mathrm{t}}$ : Supply of the must-run or auto-producers (MW) if there is any

The variables of the model are the powers loaded, coming from each type of unit (i) for each season $(\mathrm{s})$ in year $(\mathrm{t})$.

\subsection{Demand}

We know that the most important feature of electric power is its almost non-storability. This implies that production must be adjusted instantaneously to the consumption and ensures that equipment is functioning at full capacity at the time of peak demand, and even extreme spikes. Therefore, the load curve, which represents the continuing evolution of the power demand over time, is one of the fundamental elements of the power system optimization model.

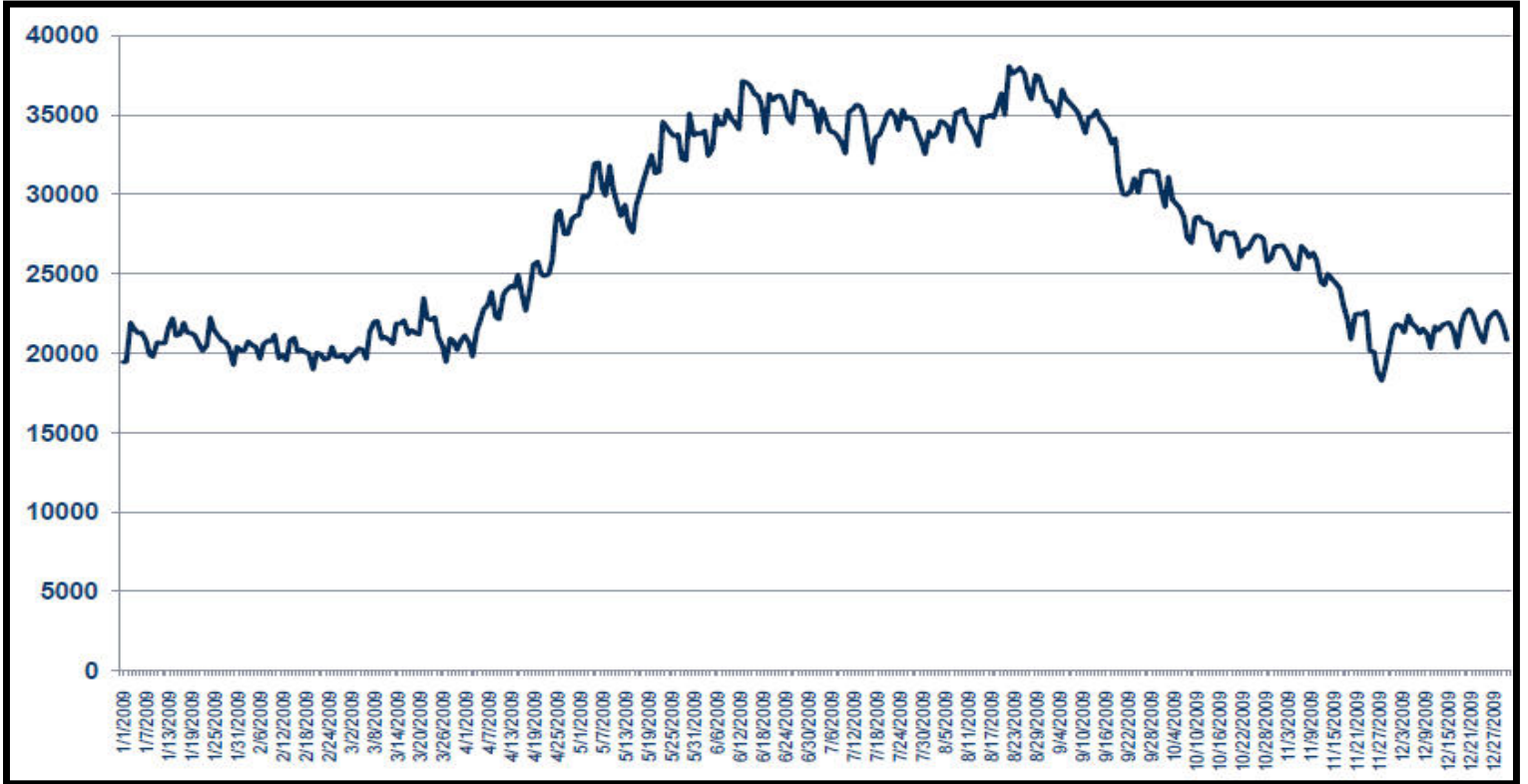

Figure 6: Annual load curve for Saudi Arabia in 2009

(Source: Electricity \& Co-generation Regulatory Authority)

Figure 6 represents the load curve of Saudi Arabia during year 2009. This demand structure has been used in the model for simulating the current generation mix of the country. As it was 
mentioned before, the total electricity demand of the country will reach $80 \mathrm{GWe}$ in 2020 and 120GWe in 2030 (SEC 2009 and ECRA 2010). Hence, future demand curves considered in the models for the year 2020 and the year 2030 increase proportionally to this demand structure up to the before-mentioned amounts.

The overall demand for electricity in Saudi Arabia has been refined by different seasons. They are defined in Table 1.

\begin{tabular}{|c|c|}
\hline $\begin{array}{c}\text { Model's } \\
\text { parameter }\end{array}$ & $\begin{array}{c}\text { Seasonal periods in Saudi } \\
\text { Arabia }\end{array}$ \\
\hline S1 & Summer \\
\hline S2 & Spring and Autumn \\
\hline S3 & Winter \\
\hline
\end{tabular}

Table 1: Seasonal definition

Demand corresponding to each season will be the demand to be met by using the available generation capacity. The reason for which three periods have been defined is the fact that in each period, the load behaviour is quite uniform. This seasonal division is shown in the Figure 5.

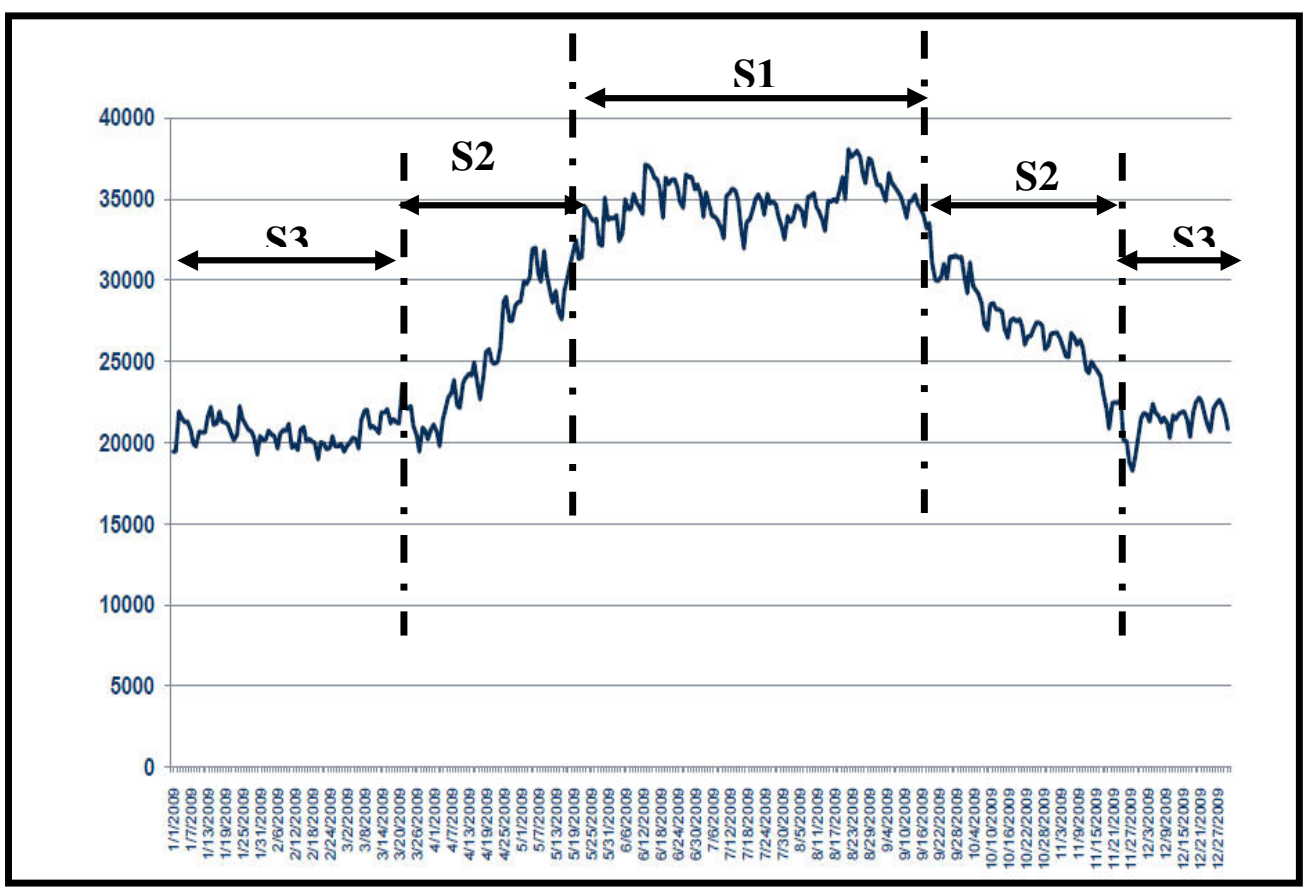

Figure 5: Seasonal periods' definition over an annual loading curve of Saudi Arabia's power sector (ECRA 2010) 


\section{$\underline{\text { Seasons }}$}

* Winter (S3): December, January, February, March

* Spring \& autumn (S2): April, May, October and November

* Summer (S1): June, July, August and September

In Saudi Arabia, periods when electricity demand is the highest correspond to the months of June, July and August and up to the end of September (S1). In our model we presume the same amount of hour for each season (S1, S2 \& S3) which is not far from the reality.

$$
S 1=S 2=S 3=\left(\frac{8760}{12}\right) \times 4=2920 h
$$

\subsection{Load factors and Back-up Plants}

The annual load factor of an electrical power plant demonstrates the ratio of the power generated by a plant and the theoretical maximum that could be produced over the year ( 8760 hours). For the nuclear and fossil-fuelled units, this annual load factor is simply determined by planned unavailability due to the maintenance or refuelling or shutdowns when the plant is not considered for dispatching. Assuming base-load generation, in this study we applied a generic $85 \%$ load factor for our nuclear and fossil-fuel based power units. Nevertheless, for solar sources, the output of the plant is impacted not only by the aforementioned unavailability factors but also by site-specific availability of solar irradiation. In this study, as it was already said in the section 3.3, we consider the load factors of $20 \%$ and $34 \%$ respectively for PV and CSP sites.

Moreover, in an attempt to cover the risk related to the intermittent production of solar power plants, we have introduced in the model a necessary investment in the fossil-fuel power plants that play the back-up role in case of insufficient capacity factor that could happen during peak consumption. In most of the regions around the world, lowest values of capacity factor for the 
intermittent technologies are observed during peak demand periods. On the contrary, in Saudi Arabia the capacity factor of solar technologies does not vary too much during peak hours because of the climatic characteristics of the country. Peak hours generally take place around 3 p.m. in summer when we have proper shining factor for the solar technologies.

In our model the absence of production from intermittent means is compensated by combined cycle plants and/or gas and fuel turbines which have around $100 \%$ of availability (capacity factor equals to 1) except for the ex-ante planned maintenance. So the total yearly cost of power generation, for the renewable-integrated power mix, includes these back-up costs.

\subsection{Fuel costs}

Fuel costs are calculated per MWh on the basis of price information available for gas, oil and uranium (IEA 2011 and World Bank 2011). In the case of gas price, we considered the average price of large gas producing countries like Canada, USA, Australia and Russia (6 \$/MMBtu), where domestic prices of natural gas can decouple from international market prices. This averaged price could be a good representative of international gas price for Saudi power sector, although the real (strongly subsidized) domestic gas price is much lower for the Saudi power producers. And for oil, Dubai dated average price over the last 4 years has been considered $(80 \$ / b b l)$, even if sometimes we use oil products in power generation which are more or less expensive than the crude itself. Despite the fact that in this study we assume stable fuel prices for the matter of simplicity; this should not be considered or interpreted as any sort of prediction of stable energy markets.

In the case of uranium the task is entirely different because the price of U3O8 (so-called yellow cake) only counts for about $5 \%$ of the total cost of power production and therefore any volatility in the price has very small impact on the total cost of electricity generation. Spotmarket plays a very limited role for the nuclear fuel (at different stages) and most of the 
activities are carried out under long term contracts. In the model we assume the nuclear fuel price of 7 \$/MWh until fuel fabrication process, plus 2.5 \$/MWh more for transport, storage and eventually reprocessing and final disposal (IEA \& NEA 2010).

\subsection{Technical properties and other costs}

Apart from fuel costs, which have already been described, the other variable and fixed costs of each type of power plant are also essential for the decision making process of the model. Plants' life-time and efficiency should also be incorporated in the model so as to be able to evaluate the potential amount of electricity (from technical point of view) that each power plant could produce. Table 2 provides the techno-economic properties of various thermal power plants used in the model. These values are derived from the studies of IEA and NEA (2010) on power generation costs.

\begin{tabular}{|l|c|c|c|c|c|}
\hline \multicolumn{2}{|c|}{ Techno-economic data for each type of power plant } \\
\hline & & & & Solar & \\
Plant type & Nuclear Plant & CCGT Plant & Fuel Plant & $P V$ & CSP \\
\hline Efficiency (\%) & 33 & 57 & 38 & $*$ & $*$ \\
\hline Investment cost (\$/Kwe) & 2050 & 534 & 364 & 3400 & 3000 \\
\hline Life cycle (years) & 60 & 30 & 30 & 25 & 25 \\
\hline Fix O\&M cost (\$/Kwe) & 46 & 8 & 8 & 50 & 60 \\
\hline Variable O\&M cost (\$/MWh) & 0.8 & 1 & 0.3 & 0.5 & 0.5 \\
\hline
\end{tabular}

Table 2 (Source: IEA 2010 Median Case)

\subsection{Model's Scenarios}

In our model we attempt to analyse the future situation of Saudi Arabia generation mix under different scenarios, respectively ten and twenty years forward. To do so, we assume the most probable scenarios for the electric mix of the country for years 2020 and 2030. Then we calculate the total yearly cost of optimal electricity generation for each specific year and scenario. Figure 10 illustrates different assumed scenarios integrated to the model. 


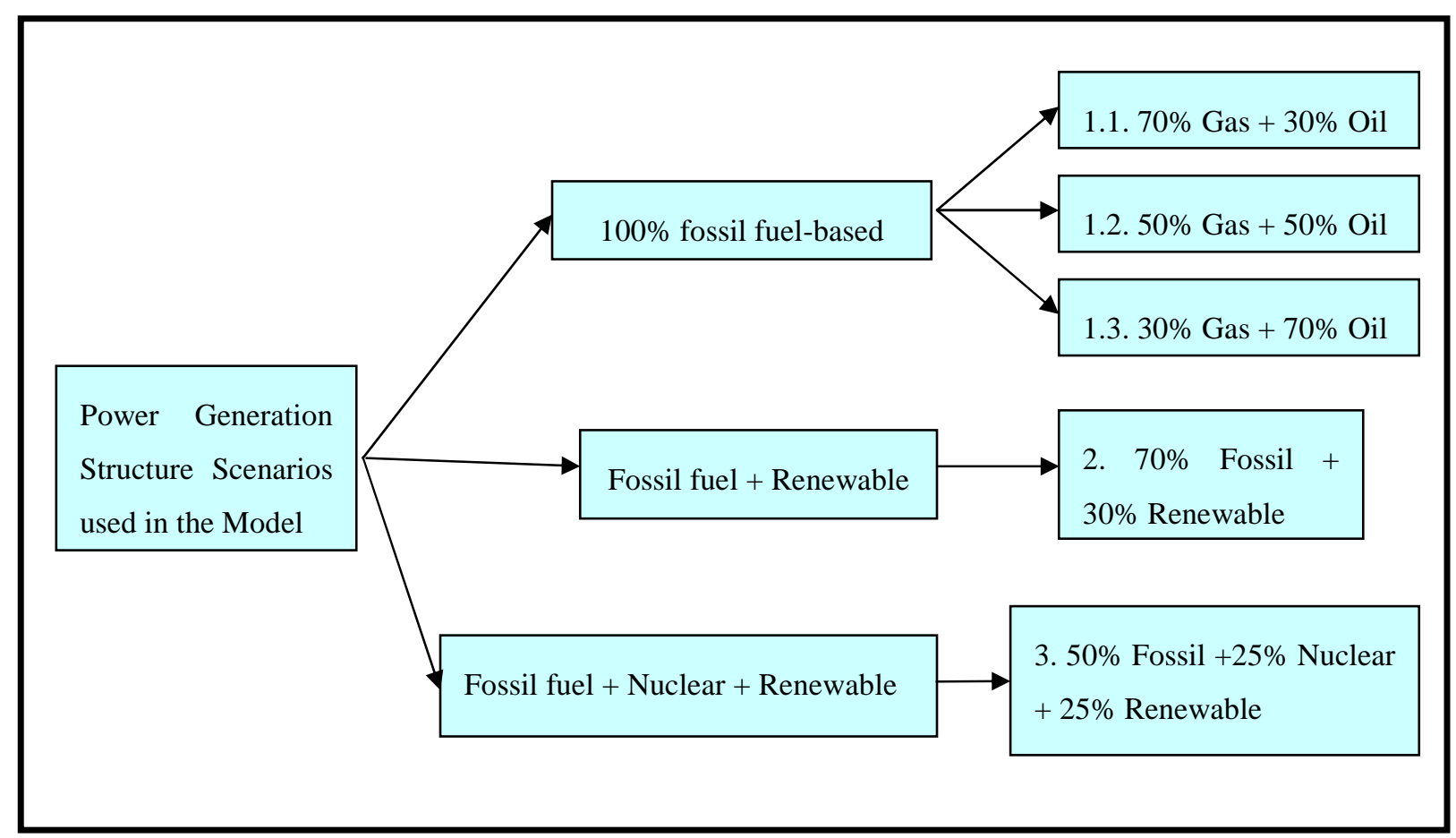

Figure 10: Scenarios considered for the electric power generation mix model of Saudi Arabia

Three main scenarios, including three sub-scenarios, have been considered for the future electricity mix of the country. In first scenario, which is our business as usual and most probable scenario, we continue the power generation of Saudi Arabia by using $100 \%$ of fossil-based (Oil \& Gas) power plants in years 2020 and 2030. Therefore, there is no investment or construction plan for nuclear and renewable energies. Investments only go for oil-based and gas-based thermal power plants. For this scenario we have defined three subscenarios which are as following:

Gas oriented mix (1-1): In which we consider $70 \%$ of the electricity production from gasbased power plant and the remaining $30 \%$ is provided by oil-based plants.

Fifty-fifty fossil fuel mix (1-2): This is our middle case sub-scenario in which half of the power production is provided by gas-based plants and the other half of it by oil-based ones. This scenario is too similar to the current power generation situation of Saudi Arabia. 
Oil oriented mix (1-3): Finally, the last assumed sub-scenario is based on the massive usage of fuel power plants. In this scenario $70 \%$ of power is generated by Oil-based plants and the remaining part would be satisfied by Gas consuming power plants.

Our second scenario for the future mix of the country contains both fossil-based and renewable resources. We assume $30 \%$ integration of renewable sources in the total generation mix of Saudi Arabia. Only solar power plants, both PV and CSP have been integrated to the model due to their remarkable efficiencies under the climatic situation of Saudi Arabia. The rest of the electric power is afforded by the fossil-based $(50 \%$ Oil \& $50 \%$ Gas) thermal power plants.

Finally our third scenario contains all the possible resources of electricity generation (Fossil, Renewable \& Nuclear). In this scenario, we assume that half of the generated power is provided by non-fossil based power plants, both Nuclear and Renewable. The share of each technology in the generation mix is equal to $25 \%$ of installed capacity.

\section{Simulation Results}

To calibrate and verify the reliability of the model, we compared the results on a reference year with the observed data provided by IEA Electricity Information and BP Electricity Generation Statistics. Table 3 shows the amount of power production in our base case (reference year 2010) generation mix and those of BP and IEA.

\begin{tabular}{|l|r|}
\hline Source & $\begin{array}{r}\text { Power } \\
\text { generation }\end{array}$ \\
\hline BP Statistics & $240 \mathrm{TWh}$ \\
\hline IEA Electricity Information & $240.3 \mathrm{TWh}$ \\
\hline Model Base Case & $239 \mathrm{TWh}$ \\
\hline
\end{tabular}

Table 3: Model's base case result validation: power production in 2010 
Thereafter we run the model for all the pre-defined scenarios. Figure 11 illustrates the total costs of power generation per year for different structures of generation mix.

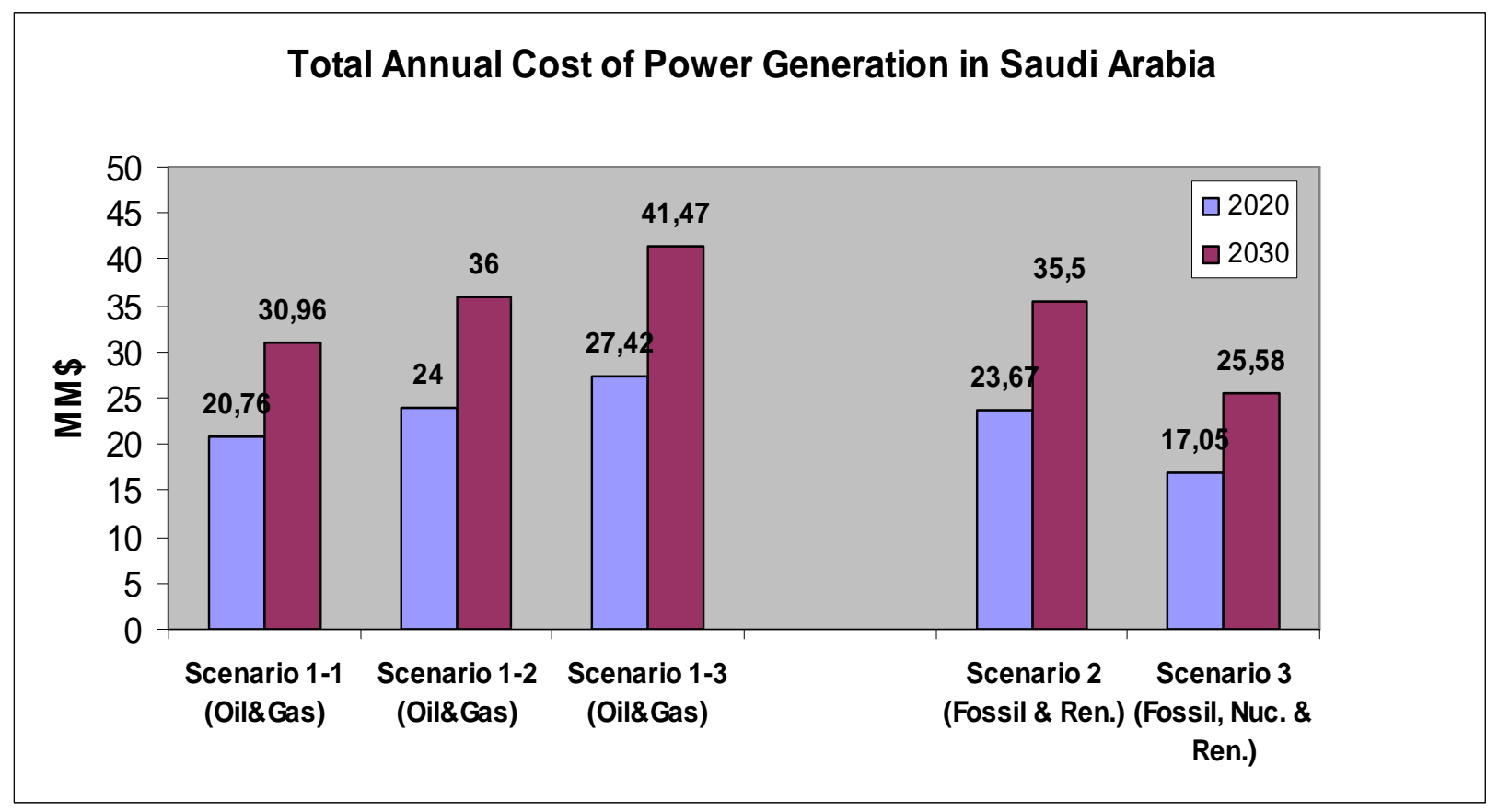

Figure 11

The first scenario (and its three related sub-scenarios) shows us the cost of electricity production during years 2020 and 2030 by using only fossil fuel based power plants. The total cost of generation (minimum and optimal cost of-course) increases dramatically when the integration rate of oil rises in the national generation mix.

Moreover, the cost difference between year 2020 and year 2030 also increases when we switch to more oil dependent mixes. The results for scenario 2 , in which we consider $30 \%$ of renewable share in the national generation mix, are not far from those of scenario 1-2 suggesting $50 \%$ of oil-consuming power plants in the system. However, it is essential to state that, this conclusion is only based on the pure economic insight and if we include also environmental externalities then the result would be different and renewable integration will certainly have more success. 
Finally the result concerning scenario 3, both nuclear and renewable integration to the national mix, illustrates the dramatic impact of nuclear plants on the total cost of power generation. For instance, the cost difference between scenario 3 and scenario 1-1 (which consumes mostly gas compare to more expensive oil) has been estimated by the model to be around 3.7 billion dollars in 2020 and even higher in 2030 (5.38 billion USD).

\section{Sensitivity \& Break-even Analysis}

In order to perform a reasonable sensitivity analysis, we have chosen to test the impact of changes in the discount rate on a total generation cost calculation. The reason behind this choice is the fact that the discount rate has more significant impact on the generation cost for capital intensive centralized generation units and at the same time it is the most uncertain factor in the case of Saudi Arabia. Oil and gas technologies and their associated O\&M and fuel costs are already very well known in Saudi Arabia and therefore we are looking for a factor (which is the discount rate in our study) that can remarkably impact the new power units such as renewable and nuclear ones. Sensitivity analysis over the other underlying parameters of generation cost, such as fuel costs, has not been considered in our study because of their rather negligible influence over the total cost of nuclear \& solar power units. In the particular case of solar plants, generally load factor variation has the most important weight in the total cost sensitivity analysis and to a lesser extent the construction cost. However, in the case of Saudi Arabia as the load factor is somehow stable (due to the regional climatic condition and important share of CSP) we focus more on the construction and initial investment costs.

The discount rate that we have considered in our model is equal to $8 \%$ based on a set of governmental studies and information regarding investments in power sector in Saudi Arabia (KACARE 2010). Sensitivity analysis has been performed for all the three scenarios. The 
impact of several discount rates on total annual generation cost for these three scenarios is shown in the Figure 12 for discount rates ranging from $5 \%$ to $15 \%$.

Logically, within higher capital cost, the total cost for all scenarios increases. On one hand, we see a relative stability of fossil-based (gas and fuel) power plants cost and therefore their almost insensitivity to cost of capital changes. On the other hand, nuclear power units, in spite of having a lower initial investment cost ratio rather than solar technologies, are the most sensitive units to discount rate changes, too simply because they have much longer construction times than any other power unit. The construction time for a nuclear plant in the model is equal to 5 years while for solar plants is only 1 year. This high sensitivity of nuclear power units compare to solar ones can be easily revealed by comparing the sensitivity results (comparative growth rate of each chart) of the two non-fossil based plants integration scenarios ( $2 \& 3)$. Therefore, financing structure and capital costs are of significant importance to investments in nuclear capacity.

Break-even analysis has also been performed for aforementioned scenarios at different discount rates. The outcome will help us to make a more rational (from economic point of view) technology choice for the national power generation. As it is shown in figure 12 , at the discount rate of $8 \%$, our pure fossil based scenario intersects the $30 \%$ renewable penetration scenario. It means that at the discount rates greater than $8 \%$, a fossil-based generation mix is more economic than that of scenario 2 . However, scenario 3 (with both nuclear and renewable penetration) remains the most economical solution. This situation continues until the discount rate of $13 \%$. Thereafter, the fossil-based scenario becomes again the best scenario (economically speaking) compare to the other two. It is important to remark that with a higher integration of gas plants in to the system this second break-even point could be pushed even more to the left. In other words, higher percentage of gas power plants in the pure fossil-based 
national mix will promote the first scenario (under the current gas price assumptions ofcourse).

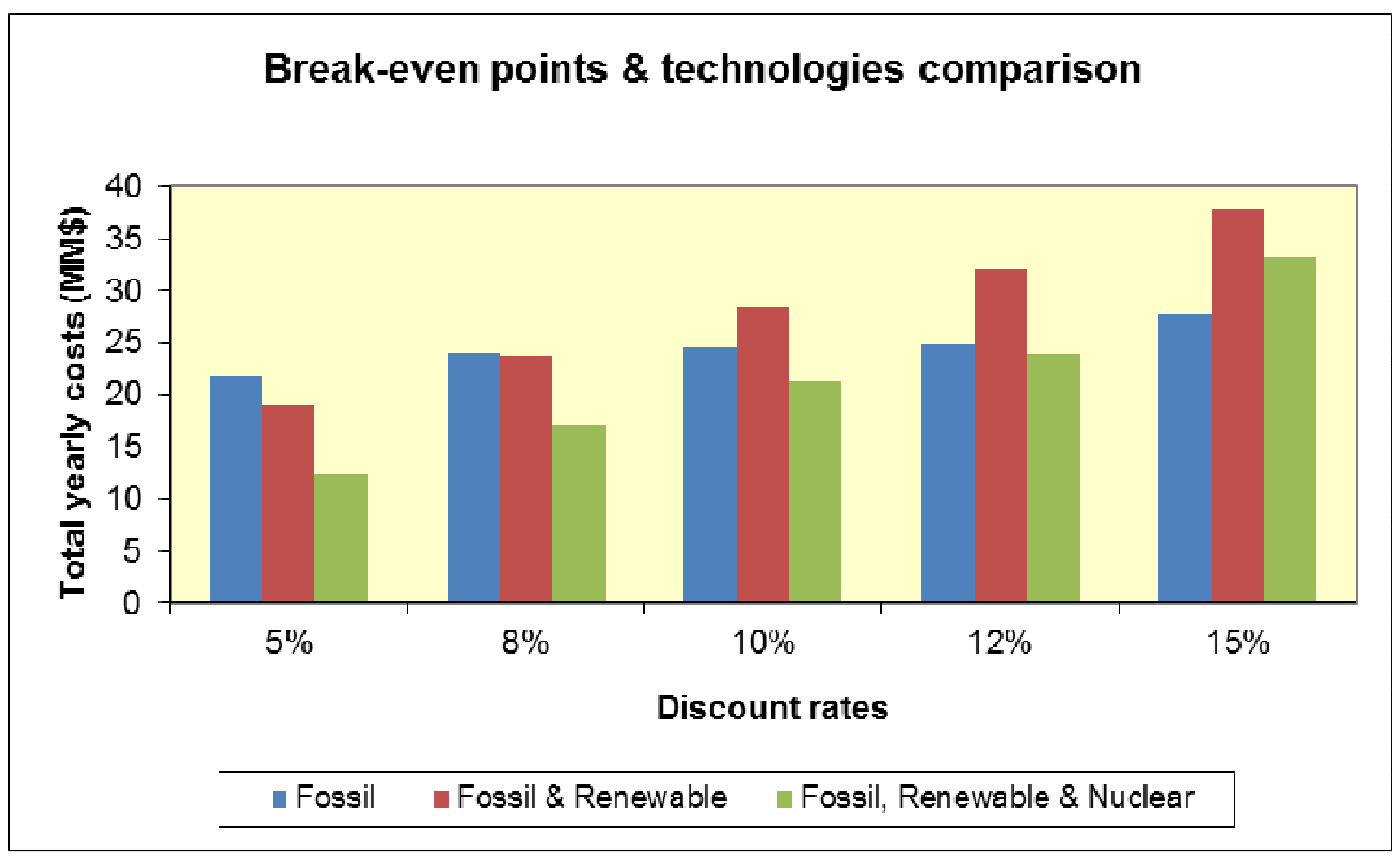

Figure 12

There is another interesting observation for our two non-fossil based scenarios at the discount rate of $12 \%$. From this point the distance between the two scenarios becomes narrower. It shows the fact that after $12 \%$ of discount rate the profitability of scenario 3 over the $2^{\text {nd }}$ one becomes less and less significant. It confirms the higher sensitivity of nuclear power plants to discount rates than that of renewable energies such as solar in our case.

\section{Economic Analysis and Interpretation}

Figure 13 shows us the important share of oil consumption in the Saudi Arabia's total oil production. In 2010, around one third of the total oil consumption went for power generation via fuel power plants. 


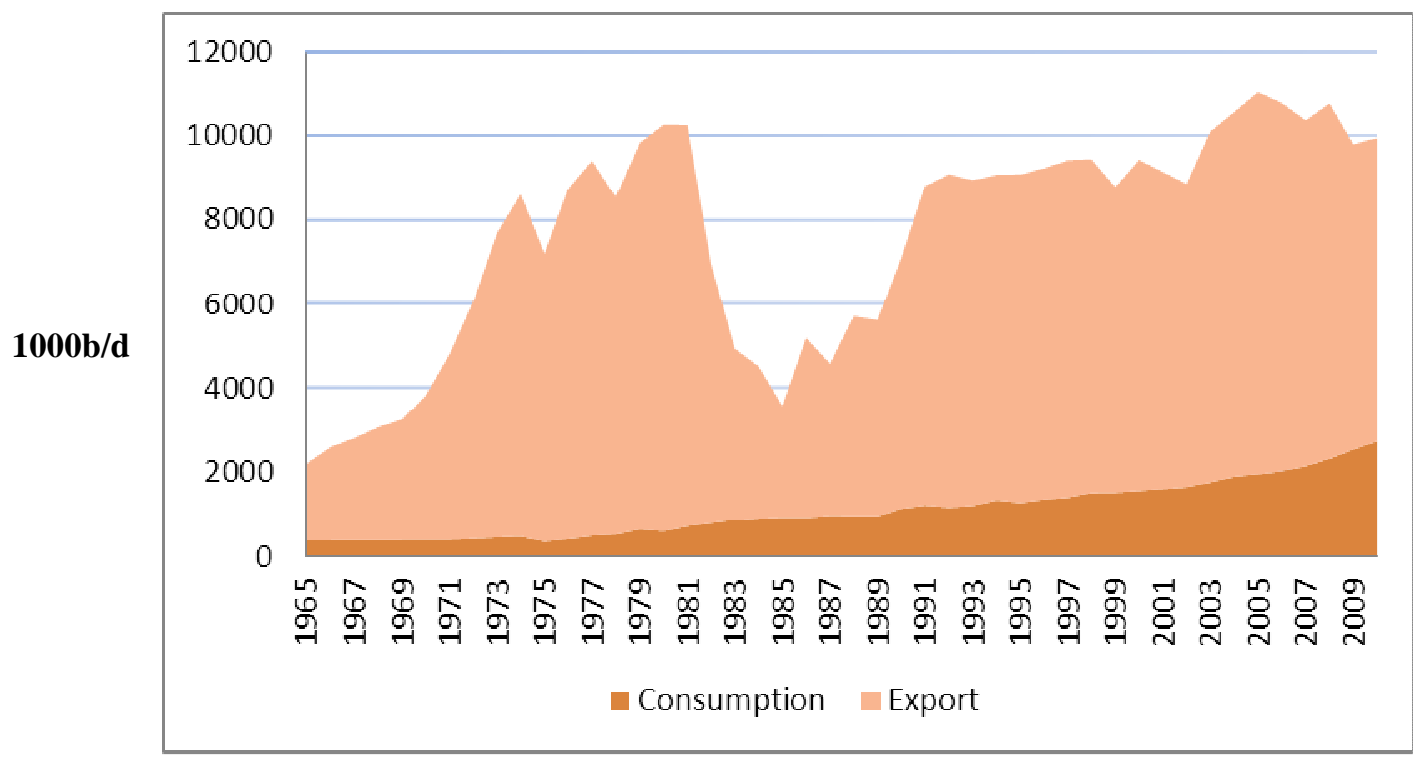

Figure 13: Saudi Arabia's oil production since 1965

(Source: BP, 2011)

This amount will proportionally increase if Saudi Arabia continues to generate electricity under its current production structure. That means, keep using oil-consuming power plants for $55 \%$ of the total electricity generation of the country.

Under the before-mentioned demand increase scenarios, total oil consumption of Saudi Arabia for power generation will reach $1.5 \mathrm{mbd}$ and $2.25 \mathrm{mbd}$, respectively in 2020 and in 2030. These numbers can become even higher if the share of oil-fired power plants goes beyond $55 \%$ of the national generation mix. As a matter of fact, Saudi Arabia can release at least $1 \mathrm{mbd}$ of crude oil by decarbonising its power generation. For instance, under scenario 2 , (30\% of renewable integration into the generation mix) Saudi Arabia will be able to put aside around $1.05 \mathrm{mb}$ per day in 2020 . This number could be easily doubled if the generation mix moves toward scenario 3 and even tripled by going beyond $25 \%$ of nuclear integration.

Eventually, switching from first group scenarios (1-1, 1-2 \& 1-3) to non-fossil fuel based scenarios will not only reduce the generation cost of electricity but will also remarkably increase the oil export revenue of Saudi Arabia. 


\section{Conclusion}

The results of the simulations of the power sector in Saudia Arabia shows us that for various scenarios of fossil-based power plant replacement, by both renewable \& nuclear ones, we can observe a remarkable cost reduction in the total power generation cost of Saudi Arabia. The same thing does not happen in the case of generation mix extension by using only renewable power plants.

By exporting the amount of oil extracted out of the generation mix (released thanks to the fuel power plant replacement) Saudi Arabia can make a massive financial and political benefits. Financial benefits, not only because of the considerable reduction in the total generation cost of electricity, but also, by raising the amount of crude oil export. Political benefits, due to an increase in their spare capacity of oil production (providing more flexibility for Saudi Arabia in terms of oil production) and consequently, an increase in its role in the OPEC and international oil market.

At the end we should emphasize on the fact that these benefits could be realized only in the case that we give an opportunity cost to the fuel that we use in the power plants. Without this hypothesis (e.g. cheaper fuel cost compare to the international market price due to subsidies) the major part of the variable cost will be vanished in the model and the benefits would become negligible.

\section{Acknowledgement}

The authors are heavily indebted to Abdulrahman ALGHABBAN and Said NACHET for their helpful comments and advices. Many people have provided helpful comments and suggestions on the analysis, and we are pleased to take this opportunity to thank them. All remaining errors are ours. The views expressed herein are strictly those of the authors and are 
not to be considered as representing those of the IFP Energies Nouvelles or University of Montpellier 1. 


\section{References}

Al-Abadi N.M., 2005, Wind energy resource assessment for five locations in Saudi Arabia, Renewable Energy, 30, pp. 1489-1499.

Alnaser W.E., Alnaser N.W., 2011, The status of renewable energy in the GCC countries. Renewable and Sustainable Energy Reviews, vol. 15 (6), pp. 3074-3098

Alnatheer O., 2006, Environmental benefits of energy efficiency and renewable energy in Saudi Arabia's electric sector. Energy Policy, vol. 34 (1), pp. 2-10.

Alotaibi S., 2011, Energy consumption in Kuwait: Prospects and future approaches. Energy Policy, vol. 39 (2), pp. $637-643$

Al-Saleh YM, Upham P, Malik K, 2008. Renewable Energy scenarios for the Kingdom of Saudi Arabia. Tyndall Centre for Climate Change Research, Working Paper 125, 64 p.

Boyle G., 2004, Renewable Energy: Power for a Sustainable Future, Oxford University Press, 3rd edition, 584 p. BP, 2011, Statistical Review of the World Energy, 48 p.

Comsan M.N.H., 2010, Nuclear electricity for sustainable development: Egypt a case study. Energy Conversion and Management, vol. 51, pp. 1813-1817

Criqui P., 2001, Prospective Outlook on Long-term Energy Systems, IEPE Report, 9 p.

Hepbasli A., Alsuhaibani Z., 2011, A Key Review on Present Status and Future Directions of Solar Energy Studies and Applications in Saudi Arabia, Renewable and Sustainable Energy Reviews, 2011, vol. 15, issue 9, pages $5021-5050$

IEA statistics, 2011, Electricity Information, IEA publishing, 883 p.

IEA statistics, 2011, Renewables Information, IEA Publishing, 497 p. 
IEA, 2011, World Energy Outlook 2011, 696 p.

IEA-NEA, 2010, Projected Costs of Generating Electricity, OECD Publishing, 216 p.

KACARE, 2010, KACARE Strategy \& Roadmap, 16 p.

Loulou R., Goldstein G. and Noble K.,2004. Documentation for the MARKAL Family of Models. Energy Technology Systems Analysis Programme. 386 p.

Lund J.W., Freestone D.H., Boyd T.L., 2005, Direct application of geothermal energy: 2005 worldwide review Geothermics, Vol. 34 (6), pp. 691-727.

MIT, 2003, The future of nuclear power, an interdisciplinary MIT study 2003. 170 p.

NEA, 2008, Nuclear Energy Outlook. OECD Ed., 460 p.

Oktun G., A.M. Sayigh, 1976. Geothermal energy in Saudi Arabia and its use in connection with solar energy. Proceedings of the international conference, Dhahran, Saudi Arabia, pp. 583-595.

Saudi Electricity Company, 2011, Annual reports 2011/2010/2009.

Taleb H.M., 2009, Barriers hindering the utilisation of geothermal resources in Saudi Arabia. Energy for Sustainable Development, vol. 13, pp. 183-188

Weber C., 2005, Uncertainty in the Electric Power Industry: Methods and Models for Decision Support, Springer Ed., 290 p.

World Bank, 2011, Data \& Research. http://econ.worldbank.org/ = J'ai un doute, est-ce-qu'il ne vaut pas mieux mettre cette reference dans des sources plutôt qu'une référence bibliographique. 


\section{The "Cahiers de I'Économie" Series}

The "Cahiers de l'économie" Series of occasional papers was launched in 1990 with the aim to enable scholars, researchers and practitioners to share important ideas with a broad audience of stakeholders including, academics, government departments, regulators, policy organisations and energy companies.

All these papers are available upon request at IFP School. All the papers issued after 2004 can be downloaded at: www.ifpen.fr

The list of issued occasional papers includes:

\section{\# 1. D. PERRUCHET, J.-P. CUEILLE}

Compagnies pétrolières internationales : intégration verticale et niveau de risque. Novembre 1990

\section{\# 2. C. BARRET, P. CHOLLET}

Canadian gas exports: modeling a market in disequilibrium.

Juin 1990

\section{\# 3. J.-P. FAVENNEC, V. PREVOT}

Raffinage et environnement.

Janvier 1991

\section{\# 4. D. BABUSIAUX}

Note sur le choix des investissements en présence de rationnement du capital. Janvier 1991

\section{\# 5. J.-L. KARNIK}

Les résultats financiers des sociétés de raffinage distribution en France 1978-89.

Mars 1991

\section{\# 6. I. CADORET, P. RENOU}

Élasticités et substitutions énergétiques : difficultés méthodologiques.

Avril 1991

\section{\# 7. I. CADORET, J.-L. KARNIK}

Modélisation de la demande de gaz naturel dans le secteur domestique : France, Italie, Royaume-Uni 1978-1989.

Juillet 1991

\section{\# 8. J.-M. BREUIL}

Émissions de SO2 dans l'industrie française : une approche technico-économique. Septembre 1991

\section{\# 9. A. FAUVEAU, P. CHOLLET, F. LANTZ}

Changements structurels dans un modèle économétrique de demande de carburant. Octobre 1991

\section{\# 10. P. RENOU}

Modélisation des substitutions énergétiques dans les pays de I'OCDE.

Décembre 1991

\section{\# 11. E. DELAFOSSE}

Marchés gaziers du Sud-Est asiatique : évolutions et enseignements.

Juin 1992

\section{\# 12. F. LANTZ, C. IOANNIDIS}

Analysis of the French gasoline market since the deregulation of prices.

Juillet 1992
\# 13. K. FAID

Analysis of the American oil futures market. Décembre 1992

\section{\# 14. S. NACHET}

La réglementation internationale pour la prévention et I'indemnisation des pollutions maritimes par les hydrocarbures.

Mars 1993

\# 15. J.-L. KARNIK, R. BAKER, D. PERRUCHET Les compagnies pétrolières : 1973-1993, vingt ans après.

Juillet 1993

\section{\# 16. N. ALBA-SAUNAL}

Environnement et élasticités de substitution dans I'industrie ; méthodes et interrogations pour l'avenir. Septembre 1993

\section{\# 17. E. DELAFOSSE}

Pays en développement et enjeux gaziers : prendre en compte les contraintes d'accès aux ressources locales. Octobre 1993

\section{\# 18. J.P. FAVENNEC, D. BABUSIAUX*}

L'industrie du raffinage dans le Golfe arabe, en Asie et en Europe : comparaison et interdépendance. Octobre 1993

\section{\# 19. S. FURLAN}

L'apport de la théorie économique à la définition d'externalité.

Juin 1994

\section{\# 20. M. CADREN}

Analyse économétrique de l'intégration européenne des produits pétroliers : le marché du diesel en Allemagne et en France.

Novembre 1994

\section{\# 21. J.L. KARNIK, J. MASSERON*}

L'impact du progrès technique sur l'industrie du pétrole. Janvier 1995

\section{\# 22. J.P. FAVENNEC, D. BABUSIAUX}

L'avenir de l'industrie du raffinage. Janvier 1995

\section{\# 23. D. BABUSIAUX, S. YAFIL*}

Relations entre taux de rentabilité interne et taux de rendement comptable.

Mai 1995

\section{\# 24. D. BABUSIAUX, J. JAYLET ${ }^{\star}$}

Calculs de rentabilité et mode de financement des investissements, vers une nouvelle méthode? Juin 1996 


\section{\# 25. J.P. CUEILLE, J. MASSERON*}

Coûts de production des énergies fossiles : situation actuelle et perspectives.

Juillet 1996

\section{\# 26. J.P. CUEILLE, E. JOURDAIN}

Réductions des externalités : impacts du progrès technique et de l'amélioration de l'efficacité énergétique.

Janvier 1997

\section{\# 27. J.P. CUEILLE, E. DOS SANTOS}

Approche évolutionniste de la compétitivité des activités amont de la filière pétrolière dans une perspective de long terme.

Février 1997

\section{\# 28. C. BAUDOUIN, J.P. FAVENNEC}

Marges et perspectives du raffinage. Avril 1997

\# 29. P. COUSSY, S. FURLAN, E. JOURDAIN, G. LANDRIEU, J.V. SPADARO, A. RABL

Tentative d'évaluation monétaire des coûts externes liés à la pollution automobile : difficultés méthodologiques et étude de cas.

Février 1998

\# 30. J.P. INDJEHAGOPIAN, F. LANTZ, V. SIMON

Dynamique des prix sur le marché des fiouls domestiques en Europe.

Octobre 1998

\section{\# 31. A. PIERRU, A. MAURO}

Actions et obligations : des options qui s'ignorent. Janvier 1999

\section{\# 32. V. LEPEZ, G. MANDONNET}

Problèmes de robustesse dans l'estimation des réserves ultimes de pétrole conventionnel. Mars 1999

\section{\# 33. J. P. FAVENNEC, P. COPINSCHI}

L'amont pétrolier en Afrique de l'Ouest, état des lieux Octobre 1999

\section{\# 34. D. BABUSIAUX}

Mondialisation et formes de concurrence sur les grands marchés de matières premières énergétiques : le pétrole.

Novembre 1999

\section{\# 35. D. RILEY}

The Euro

Février 2000

\section{\# 36. D. BABUSIAUX, A. PIERRU*}

Calculs de rentabilité et mode de financement des projets d'investissements : propositions méthodologiques.

Avril 2000 \& septembre 2000

\section{\# 37. P. ALBA, O. RECH}

Peut-on améliorer les prévisions énergétiques ? Mai 2000

\section{\# 38. J.P. FAVENNEC, D. BABUSIAUX}

Quel futur pour le prix du brut? Septembre 2000

\section{\# 39. S. JUAN, F. LANTZ}

La mise en œuvre des techniques de Bootstrap pour la prévision économétrique : application à l'industrie automobile Novembre 2000
\# 40. A. PIERRU, D. BABUSIAUX

Coût du capital et étude de rentabilité $d^{\prime}$ investissement : une formulation unique de I'ensemble des méthodes.

Novembre 2000

\section{\# 41. D. BABUSIAUX}

Les émissions de $\mathrm{CO} 2$ en raffinerie et leur affectation aux différents produits finis

Décembre 2000

\section{\# 42. D. BABUSIAUX}

Éléments pour l'analyse des évolutions des prix du brut.

Décembre 2000

\section{\# 43. P. COPINSCH}

Stratégie des acteurs sur la scène pétrolière africaine (golfe de Guinée). Janvier 2001

\section{\# 44. V. LEPEZ}

Modélisation de la distribution de la taille des champs d'un système pétrolier, Log Normale ou Fractale ? Une approche unificatrice.

Janvier 2001

\section{\# 45. S. BARREAU}

Innovations et stratégie de croissance externe : Le cas des entreprises parapétrolières. Juin 2001

\section{\# 46. J. P. CUEILLE*}

Les groupes pétroliers en 2000 : analyse de leur situation financière. Septembre 2001

\section{\# 47. T. CAVATORTA}

La libéralisation du secteur électrique de I'Union européenne et son impact sur la nouvelle organisation électrique française Décembre 2001

\section{\# 48. P. ALBA, O. RECH}

Contribution à l'élaboration des scénarios énergétiques. Décembre 2001

\section{\# 49. A. PIERRU*}

Extension d'un théorème de dualité en programmation linéaire : Application à la décomposition de coûts marginaux de long terme. Avril 2002

\section{\# 50. T. CAVATORTA}

La seconde phase de libéralisation des marchés du gaz de l'Union européenne : enjeux et risques pour le secteur gazier français. Novembre 2002

\# 51. J.P. CUEILLE, L. DE CASTRO PINTO COUTHINO, J. F. DE MIGUEL RODRÍGUEZ*

Les principales compagnies pétrolières indépendantes américaines : caractéristiques et résultats récents. Novembre 2002

\section{\# 52. J.P. FAVENNEC}

Géopolitique du pétrole au début du XXI ${ }^{\mathrm{e}}$ siècle Janvier 2003

\section{\# 53. V. RODRIGUEZ-PADILLA avec la collaboration de} T. CAVATORTA et J.P. FAVENNEC, *

L'ouverture de l'exploration et de la production de gaz naturel au Mexique, libéralisme ou nationalisme Janvier 2003 


\section{\# 54. T. CAVATORTA, M. SCHENCKERY}

Les majors pétroliers vers le multi énergies : mythe ou réalité ?

Juin 2003

\section{\# 55. P.R. BAUQUIS}

What energy sources will power transport in the 21st century?

Janvier 2004

\section{\# 56. A. PIERRU, D. BABUSIAUX}

Evaluation de projets d'investissement par une firme multinationale : généralisation du concept de coût moyen pondéré du capital et conséquences sur la valeur de la firme.

Février 2004

\section{\# 57. N. BRET-ROUZAUT, M. THOM}

Technology Strategy in the Upstream Petroleum Supply Chain

Mars 2005

\section{\# 58. A. PIERRU}

Allocating the $\mathrm{CO}_{2}$ emissions of an oil refinery with Aumann-Shapley prices.

June 2005

\section{\# 59. F. LESCAROUX}

The Economic Consequences of Rising Oil Prices. Mai 2006

\section{\# 60. F. LESCAROUX, O. RECH}

L'origine des disparités de demande de carburant dans l'espace et le temps : l'effet de la saturation de l'équipement en automobiles sur l'élasticité revenu. Juin 2006

\section{\# 61. C. I. VASQUEZ JOSSE, A. NEUMANN}

Transatlantic Natural Gas Price and Oil Price Relationships - An Empirical Analysis. Septembre 2006

\section{\# 62. E. HACHE}

Une analyse de la stratégie des compagnies pétrolières internationales entre 1999 et 2004 Juillet 2006

\section{\# 63. F. BERNARD, A. PRIEUR}

Biofuel market and carbon modeling to evaluate French biofuel policy.

Octobre 2006

\# 64. E. HACHE

Que font les compagnies pétrolières internationales de leurs profits? Janvier 2007

\section{\# 65. A. PIERRU}

A note on the valuation of subsidized Loans Janvier 2007

\section{\# 66. D. BABUSIAUX, P. R. BAUQUIS}

Depletion of Petroleum Reserves and Oil Price trends Septembre 2007

\section{\# 67. F. LESCAROUX}

Car ownership in relation to income distribution and consumers's spending decisions. Novembre 2007

\section{\# 68. D. BABUSIAUX, A. PIERRU}

Short-run and long-run marginal costs of joint products in linear programming Juin 2008

\section{\# 69. E. HACHE}

Commodities Markets: New paradigm or new fashion? Juillet 2008

\section{\# 70. D.BABUSIAUX, A. PIERRU}

Investment project valuation: A new equity perspective Février 2009

\section{\# 71. O. MASSOL, S. TCHUNG-MING}

Stratégies coopératives dans l'industrie du GNL : l'argument de la rationalisation est-il fondé ? Février 2009

\section{\# 72. A. PIERRU, D.BABUSIAUX}

Valuation of investment projects by an international oil company: A new proof of a straightforward, rigorous method

Février 2009

\section{\# 73. E. SENTENAC CHEMIN}

Is the price effect on fuel consumption symmetric? Some evidence from an empirical study Avril 2009

\section{\# 74. E. HACHE}

OBAMA : Vers un green New Deal énergétique? Septembre 2009

\section{\# 75. O. MASSOL}

Cost function for the natural gas transmission industry: further considerations Septembre 2009

\# 76. F. LANTZ, E. SENTENAC CHEMIN

Analyse des tendances et des ruptures sur le marché automobile français. Modélisation du taux de diésélisation dans le parc Décembre 2010.

\# 77. B. CHÈZE, P. GASTINEAU, J. CHEVALLIER Forecasting air traffic and corresponding Jet-Fuel Demand until 2025 Décembre 2010 .

\section{\# 78. V. BREMOND, E. HACHE, V. MIGNON} Does OPEC still exist as a cartel? An empirical investigation Mars 2011.

\section{\# 79. I. ABADA, O. MASSOL}

Security of supply and retail competition in the European gas market. Some model-based insights. Mars 2011.

\section{\# 80. E. HACHE, F. LANTZ}

Oil price volatility: an econometric analysis of the WTI market. Avril 2011

\# 81. I. ABADA, V. BRIAT, O. MASSOL Construction of a fuel demand function portraying interfuel substitution, a system dynamics approach. Avril 2011

\# 82. E. LE CADRE, F. LANTZ, P-A. JOUVET

The bioenergies development: the role of biofuels and the $\mathrm{CO} 2$ price. Décembre 2011

\# 83. E. LE CADRE, F. LANTZ, A. FARNOOSH Bioenergies usages in electricity generation utility means through a modelling approach: application to the French case.

Décembre 2011 
\# 84. I. ABADA, V. BRIAT, S. GABRIEL, O. MASSOL A generalized Nash-Cournot model for the northwestern European natural gas markets with a fuel substitution demand function: the GaMMES model. Décembre 2011

\section{\# 85. O. MASSOL, A. BANAL-ESTAÑOL}

Export diversification and resource-based industrialization: the case of natural gas. Décembre 2011

\section{\# 86. B. CHÈZE, P., GASTINEAU, J. CHEVALLIER}

Air traffic energy efficiency differs from place to place: analysis of historical trends by geographical zones using a macro-level methodology.

Décembre 2011

\section{\# 87. D. LORNE, S. TCHUNG-MING}

The French biofuels mandates under cost uncertainty an assessment based on robust optimization.

Septembre 2012

\section{\# 88. L. de MAACK, F. LANTZ}

Petroleum products price interactions on the world markets: an econometric analysis.

Septembre 2012

\section{\# 89. O. MASSOL, S. TCHUNG-MING}

Joining the CCS Club! Insights from a Northwest

European $\mathrm{CO}_{2}$ Pipeline Project.

Octobre 2012

\# 90. F.M. MENTEN, S. TCHUNG-MING, D. LORNE, F. BOUVART

Lessons from the use of a long-term energy model for consequential life cycle assessment: the BTL case. Novembre 2013

\section{\# 91. A. CHEVALIER, F. LANTZ}

Personal car or shared car? Predicting potential modal shifts from multinomial logit models and bootstrap confidence intervals Novembre 2013

\section{\# 92. A. FARNOOSH, F. LANTZ, J. PERCEBOIS}

Electricity generation analyses in an oil-exporting country: Transition to non-fossil fuel based power units in Saudi Arabia

Décembre 2013

\footnotetext{
* une version anglaise de cet article est disponible sur demande
} 